\title{
Hypotrophic Roots of the Upper Central Incisors - a Proposed New Discrete Dental Trait
}

\author{
Claudia Cunha ${ }^{1}$, Ana Maria Silva ${ }^{1 *}$, Joel Irish ${ }^{2}$, G. Richard Scott ${ }^{3}$, Tiago Tomé ${ }^{1}$, José \\ Marquez $^{4}$ \\ ${ }^{1}$ Research Centre for Anthropology and Health, Faculdade de Ciências e Tecnologia, Universidade \\ de Coimbra, Departamento de Ciências da Vida, Apartado 3046 3001-401 Coimbra, Portugal \\ 2 Department of Anthropology, University of Alaska - Fairbanks, PO Box 757720 \\ Fairbanks, AK 99775-7720, USA \\ ${ }^{3}$ Department of Anthropology, University of Nevada Reno, NV89557, USA \\ ${ }_{4}^{4}$ Tera Servicios de Arqueología S. L. Morería, 2, 06800 , Merida (Badajoz), España
}

Key words: Dental morphology, Upper Central Incisors, Discrete Dental Trait, Prehistory, Iberian Peninsula.

ABSTRACT This paper describes a newly defined nonmetric trait in the human dentition, i.e., Hypotrophic Roots of the Upper Central Incisors (HRUCI). Teeth presenting HRUCI are characterized by abnormally short roots whose crowns

In the mid $20^{\text {th }}$ century, A. A. Dahlberg devised a set of standardized plaster casts to be used as scoring aids in recording the expression of discrete dental traits (Turner et al., 1991). Subsequently, publications in the 1970s through 2000s by Turner, Scott and others at Arizona State University helped to expand, systematize, and broadly disseminate the methodology commonly used today to score traits: the Arizona State University Dental Anthropology System (ASUDAS) (Turner et al., 1991; Scott and Turner, 1997). From a genetic standpoint these features are "discontinuous or quasi-continuous traits that are either present or absent or present in various degrees of expression" (Larsen, 2002:137-138). In living populations, first degree relatives have frequencies of some traits six times higher than in the general population (Mays, 1998). Statistical tests applied to the observation of discrete dental traits have helped answer questions on genetic proximity/distance within groups (Gorsky et al., 1998) and between groups (Matsumura, 2007) and questions of ancestry among contemporary groups (Larsen, 2002) as well as archaeological populations (Irish, 2006; Jackes et al., 1997; Jackes and Lubell, 1999). Such traits have been used as a basis for inferences on the peopling of geographic regions (Larsen, 2002; Silva, 2002) or for the understanding of population dynamics in times of crisis, or population, cultural and/or technologi exhibit no apparent morphological alterations. The trait was observed in six samples from collective funerary sites in the Iberian Peninsula dated from the Late Neolithic to the Chalcolithic period.

cal shifts (Silva, 2002; Vargiu et al., 2009).

Despite the considerable research and number of publications produced, the ASUDAS is continually 'under construction' (Scott, 2008). New contributions and changes are ongoing. New casts have been created and scoring grades for previously non-scored traits were recently published (Wu and Turner, 1993; Burnett et al., 2010). Moreover, new traits have been described and further discoveries are expected in under-studied regions and/or populations (Weets, 2009).

The study of dental remains from several human skeletal collections dated from the Late Neolithic to the Chalcolithic period allowed the observation of an unusual root feature. European collections are characterized by simple morphology (Scott and Turner, 1988). However, individuals from the collections included in the present study exhibit various atypical characters - including UI1 presenting unusually short roots. The aim of this paper is to describe this 'new' discrete trait and discuss its frequency in six Late Prehis-

\footnotetext{
*Correspondence to: Claudia Cunha, Research Centre for Anthropology and Health, Faculdade de Ciências e Tecnologia, Universidade de Coimbra, Departamento de Ciências da Vida, Apartado 3046 3001-401 Coimbra, Portugal. Email: claudia.cunha.k@gmail.com Grant Sponsors: Fundação para Ciência e a Tecnologia (Portuguese Ministry for Science, Technology and Higher Education), Grant No. SFRH-BD-70495-2010
} 


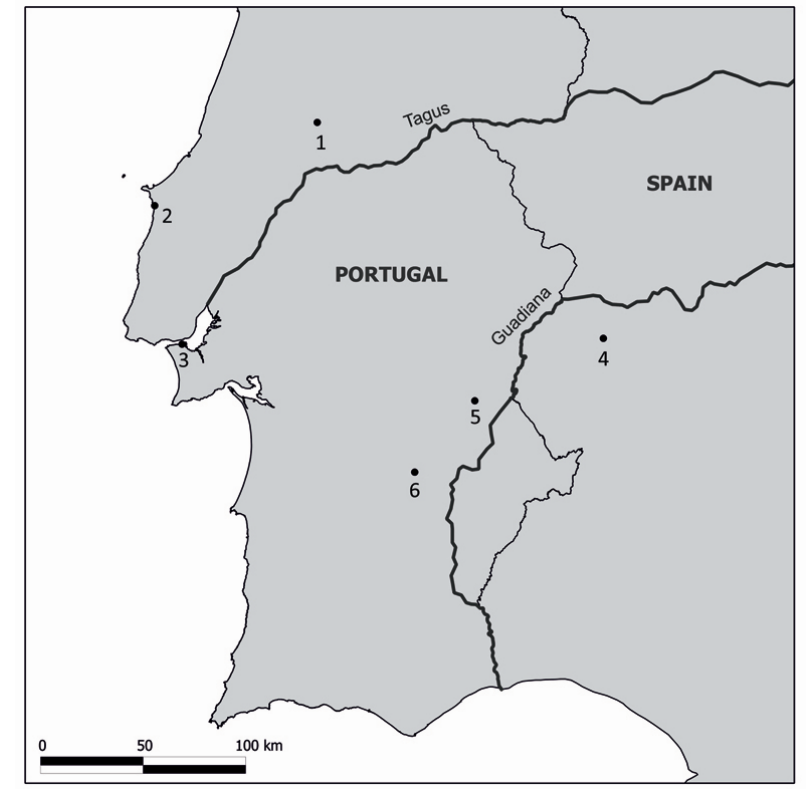

Fig. 1. (1) Cadaval Cave; (2) Tholos of Paimogo I; (3) Hypogeum of São Paulo II; (4) Monument of Cerro de las Baterías; (5) Perdigões ; (6) Pit burial.

toric population samples from different regions of the Iberian Peninsula (Fig. 1).

\section{CLINICAL APPROACH TO SHORT ROOTS}

Most of the dental literature deals with the occurrence of short roots in the human dentition from a clinical perspective in Modern populations. Specifically, the focus is related to orthodontic treatment. Hölta et al. (2004) suggest there are two general reasons for short roots: disturbances during root development, and resorption of originally well developed roots. A genetic etiology of short roots, particularly for UI1, is proposed by some (Lind, 1972; Jakobsson and Lind, 1973; Apajalahti et al., 1999; Apajalahti, 2004; Edgcomb , et al., 2011). However, the phenomenon is usually dealt with as an 'anomaly' or morphological alteration, i.e., resorption of the roots. Resorption is thought to be triggered by one or more external factors, including: (1) trauma from orthodontic treatments, surgical procedures, and occlusal pressure; (2) anticancer therapy with chemotherapeutic drugs and radiation, and/or (3) industrialized toxins such as dioxins (Ando et.al, 1967; Hylander, 1977; Brezniak and Wasserstein, 2002a, b; Apajalahti, 2004).

Population (Ando et al., 1967; Jakobsson and Lind, 1973; Thongudomporn and Freer, 1998), family (Apajalahti et al., 1999) and longitudinal studies (Ando et.al, 1967; Hölta et al., 2004) indicate that short roots in UI1 is a genetically controlled feature (Brezniak and Wasserstein (2002a) state that root resorption is "an unavoidable consequence of orthodontic tooth movement."). It is more frequent in females than males at a ratio of 2.7:1 (Jakobsson and Lind, 1973; Thongudomporn and Freer, 1998); moreover, there are differences in frequencies among populations (Table 1), and it may have an autosomal dominant pattern of transmission (Apajalahti et al., 1999). In cases where resorption is not considered the cause, shortened roots are bilaterally expressed (Jakobsson and Lind, 1973; Marques et al., 2010). However, as far as we know, this trait has not

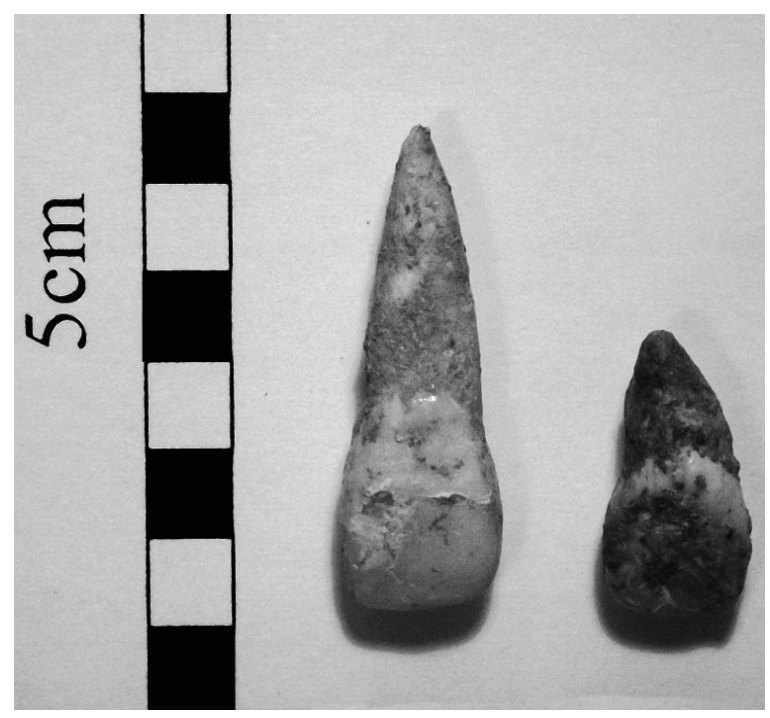

Fig. 2. UI1 presenting average sized root (left) and another displaying HRUCI (right), both from Cerro de las Baterías, Spain.

TABLE 1. Prevalence of Bilateral Short Roots in UII

\begin{tabular}{cccc}
\hline Ethnic Group/Origin & $\mathbf{n}$ & Prevalence & Reference \\
\hline Mongoloid (Japanese) & 300 & $10 \%$ & Ando et.al, 1967. \\
Caucasian (Swedish) & 1038 & $2.4 \%$ & Jakobsson and Lind, 1973. \\
Caucasian (?) (Australia) & 111 & $23.4 \%$ & Thongudomporn and Freer, 1998. \\
\hline
\end{tabular}


been employed as a normal epigenetic variant of the human dentition.

\section{MATERIALS AND METHODS}

Trait Description: Lind (1972) developed a metric method to record the phenomenon by determining the ratio between root length and crown height ( $\mathrm{R} / \mathrm{C}$ value) for the UI1; the method was later applied to a sample of 1,038 white children of both sexes (Jakobsson and Lind, 1973). The latter study reported a mean $R / C$ value of UI1 with fully developed roots of 1.63 for males

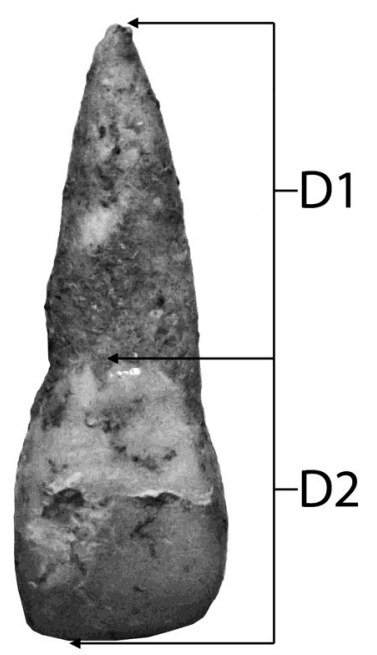

Fig. 3. Distances measured in order to obtain the length of roots and crowns of incisors included in the study.

and 1.55 for females. Dimorphic differences were not significant, and when the sexes were pooled the general mean $\mathrm{R} / \mathrm{C}$ value was 1.6.

The trait that we observed can be described as the occurrence of substantially shorter roots for UI1 that are either equal to, or shorter than the incisor crown height. For this trait, the crowns themselves are normal in appearance, and no other teeth exhibit root diminution. We propose that this trait, defined by a root:crown ratio of $<1.5: 1$, be named Hypotrophic Roots of the Upper Central Incisors (HRUCI) (Fig. 2). Further studies on samples both within and outside Portugal are planned to assess the trait's presence in other local and world regions; it also will be determined if simple presence/absence scoring, like that in ASUDAS, is warranted for this trait.

Both crowns and roots of UI1 in all samples were measured using a Mitutoyo Digimatic caliper with an accuracy of $0.01 \mathrm{~mm}$. Measures were taken in labial view. Root length was measured between its apex and the cement-enamel junction in the sagittal plane of the tooth (D1 in Fig. 3). The crown length was measured between the cement-enamel junction, again in the mid-sagittal plane, to the most occlusal point of the incisal edge (D2 in Fig. 3). Teeth exhibiting roots of equal length or shorter than the crown were considered to present HRUCI.

Teeth with incisal wear of grade 3 and above [scale proposed by Smith (1984), as modified by Silva (1996)] were excluded from the study for two reasons: first, to avoid shortening of roots resulting from occlusal trauma caused by pressure loading; and second, because severe tooth wear would interfere in the crown-root ratio. For the same reason fragmented incisors and others in early stages of development were not considered. Only teeth with an apex almost or completely closed were measured, i.e. individuals older than 8 yrs of age (Smith, 1991).

Presence/absence dichotomy of the trait was registered to obtain the frequency of HRUCI in the collections.

\section{Samples}

Cadaval (CDV) is one of the burial caves in the limestone region of Canteirões in the Nabão river valley - a sub-tributary of the Tagus river, Portugal. Radiocarbon dates from the human skeletal material indicate that CDV was in use between the third quarter of the $5^{\text {th }}$ millennium and middle of the $4^{\text {th }}$ millennium BC (Tomé, 2011).

Cerro de las Baterías is a funerary monument located in the Province of Badajoz, Spain (Fig. 1) near the town of La Albuera in the Guadiana River Basin. Although ${ }^{14} \mathrm{C}$ dating was impossible due to taphonomic factors, the funerary assemblage accompanying the human remains presents clear parallels with local archaeological contexts dating to the $3^{\text {rd }}$ millennium $B C$ for this region of the Iberian Peninsula (Márquez Gallardo, 2008).

The vaulted chamber tomb (tholos) of Paimogo 1 (PMI) and the hypogeum of São Paulo II (SPII) 
are located in the same geomorphological region in the Southwest coast of the Iberian Peninsula. Radiocarbon dating places the use of PMI between the end of the $4^{\text {th }}$ millennium and the mid $3^{\text {rd }}$ millennium BC. Radiocarbon dating on human remains produced dates in the $3^{\text {rd }}$ millennium BC for SPII (for detailed osteological data on these samples see Silva, 2002; 2003).

The tholos-like structures of tombs 1 and 2 of Perdigões (PDG) have absolute dates pointing to the $3^{\text {rd }}$ millennium BC. The site is located in Reguengos de Monsaraz, Southeast Portugal (Map1) (Valera and Godinho, 2009).

The pit burial of Monte das Covas 3 (MCOV3) is a collective funerary monument for which there are no absolute dates. Typologically this type of inhumation was in use from the Late Neolithic to Bronze Age. The site is located near Beja, Portugal (Miguel and Brazuna, 2008).

In all sites except Monte das Covas 3, skeletons were disarticulated. Although all teeth in this study come from fragmented maxillae, the skulls from Monte das Covas 3 were removed en bloc from the field and excavated in the labora-
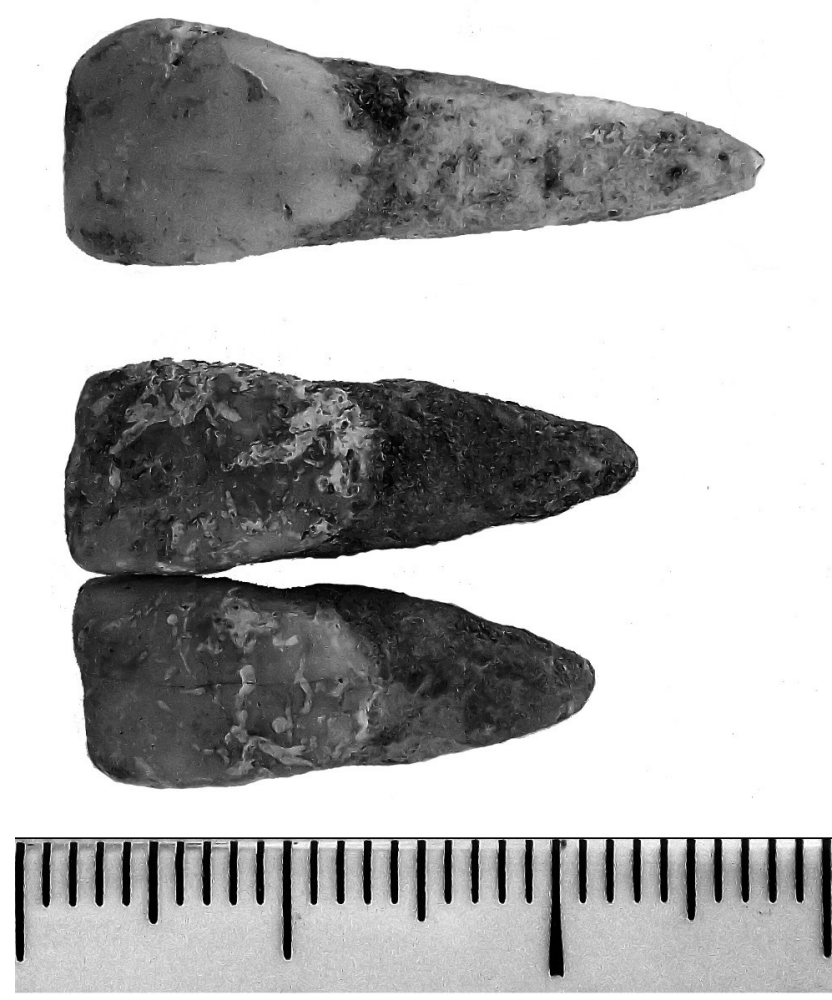

Fig. 4. A pair of compatible UI1 from BT07 displaying HRUCI (below) and a right presenting UI1 regular root length (above). tory; this approach allowed the identification of individuals in addition to isolated teeth from undetermined individuals.

Due to the nature of the trait described in this article, identification can only be made in loose teeth or via medical imaging (e.g., radiographs, $\mathrm{CT} / \mathrm{CAT}$ scans). Cases described here were observed in loose, unassociated teeth, although in the BT07 samples compatibility of antimeres was observed (Fig. 4), and in MCOV3 the loose teeth could be assigned to individual skulls.

The Tagus and Guadiana rivers, along with their tributaries, form major routes for population movement in the southern inland of the Iberian Peninsula; thus, a specific pattern of genetic exchange is likely. Cerro de las Baterías and Perdigões are inland sites near the Guadiana river, while Cadaval is located in the Tagus Basin. The other sites, Paimogo I and São Paulo II, are geographically more prone to coastal influences. The populations from Paimogo I and São Paulo II might have had other genetic influences from groups living on and moving along the Atlantic coast.

\section{RESULTS AND DISCUSSION}

Table 2 presents the total number of UI1 in the samples, the number of specimens considered for the study, and the frequencies of the trait. Several other teeth excluded from the study appeared to exhibit HRUCI, but could not be measured and included in the total numbers due to missing portions of their anatomy.

The frequency of HRUCI differs significantly between samples from the inland sites of CDV, BT07, PDG and MCOV3 and the coastal sites of PMI and SPII. Coastal sites present a frequency under $16 \%$ while inland sites have frequencies above $20 \%$. This variation may suggest a different composition of the coastal populations, different patterns of genetic exchange, and/or high endogamy in the inland sites. Further study of other coeval coastal and inland populations is necessary to support any of these hypotheses.

Concerning possible causes that lead to the shortened roots, one common reason, suggested in archaeological, ethnographic (Hylander, 1977) and clinical publications (Ando et al., 1967; Apajalahti, 2004; Silva Filho et al., 2007), is heavy occlusal pressure. This factor is not likely attributable to HRUCI in the present samples. Load/bite 
TABLE 2. Frequencies of HRUCI in the sites of Cadaval (CDV), Perdigões (PDG), Cerro de las Baterías (BT07), Paimogo I (PMI), São Paulo II (SPII) and Monte das Covas 3 (MCOV3) per side of jaw.

\begin{tabular}{ccccccc}
\hline & \multicolumn{2}{c}{$\begin{array}{c}\text { Total of UI1 in the } \\
\text { collection }\end{array}$} & \multicolumn{2}{c}{ Measured UI1 } & \multicolumn{2}{c}{ UI1 Presenting HRUCI } \\
\hline Site & Left & Right & Left & Right & Left & Right \\
CDV & 10 & 11 & 3 & 6 & $1(33.3 \%)$ & $3(50.0 \%)$ \\
PDG & 50 & 31 & 25 & 11 & $5(20.0 \%)$ & $3(27.3 \%)$ \\
BT07 & 80 & 87 & 37 & 28 & $15(40.5 \%)$ & $10(35.8 \%)$ \\
PMI & 119 & 103 & 108 & 90 & $17(15.7 \%)$ & $11(12.2 \%)$ \\
SPII & 89 & 76 & 66 & 59 & $10(15.2 \%)$ & $8(13.6 \%)$ \\
MCOV3 & 10 & 13 & 5 & 7 & $2(40.0 \%)$ & $3(42.9 \%)$ \\
\hline
\end{tabular}

force resulting in resorption or premature closure of the UI1 radicular apex would have been distributed along the other anterior teeth, particularly in lower incisors to cause shortening of their roots as well. In the sample of Cerro de las Baterías, 158 loose lower incisors (LI1 and LI2) presenting closed apex and intact roots were observed to determine if a similar frequency of shortened roots matched that for UI1. Only three teeth $(1.89 \%)$ presented apparently short roots, and none of the LI1 and LI2 presented roots

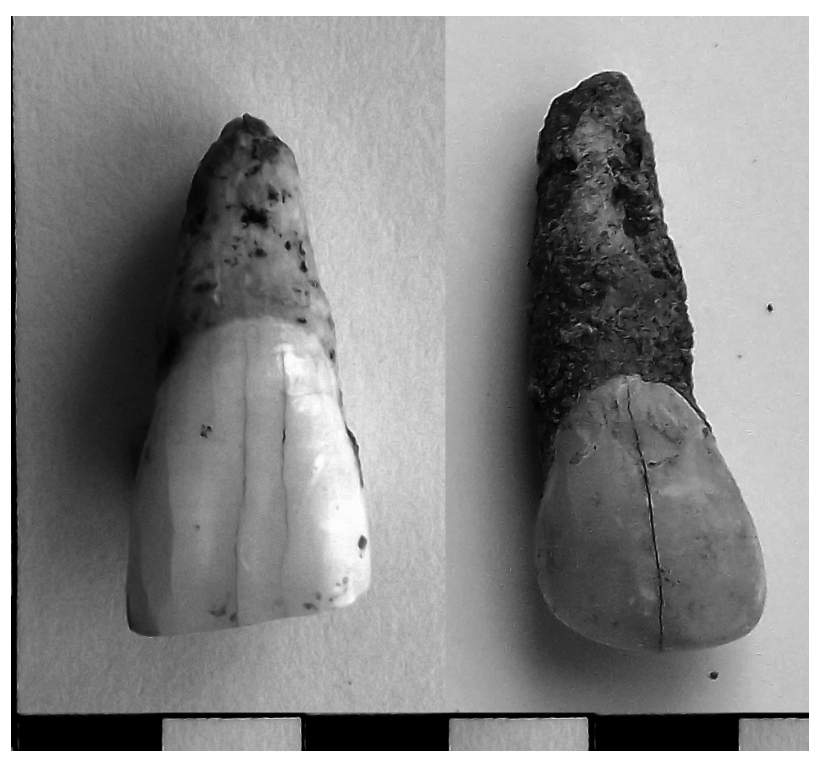

Fig. 5. Smooth root surface on a HRUCI UI1 (right) and irregular surface of a blunt root in a UI2 (left) presenting evidence of hypercementosis. equal or shorter than crowns. Hypercementosis, another result of heavy occusal trauma, is absent in UI1 from the samples.

In cases of severe root resorption from repetitive or continuous trauma (e.g., occlusal trauma, tooth movement, etc.), shortening appears to be the natural response of the organism to repair the affected area. In such cases, dentin layers beneath the cementum are affected. The repair process generally begins two weeks after forces that caused the trauma end, and involve active cementum deposition (Brezniak and Wasserstein, 2002a). In archaeological material the most obvious result of this repair process is an irregular layer of cementum altering the physiologic limits of the root - hypercementosis (Fig. 5). Although there are cases of hypercementosis in the present study, none affected UI1.

Other factors listed for shortening of roots in contemporary populations (i.e., clinical treatments, drug use, contamination by chemical agents) do not fit the profile for the Prehistoric samples. Therefore, a genetic etiology for the phenomenon seems to be the most likely explanation. Clinical literature suggests that at least part of the cases studied in Contemporary populations appear to have a genetic pattern of inheritance and family prevalence (Lind, 1972; Jakobsson and Lind, 1973; Apajalahti et al., 1999; Edgcomb et al., 2011). Observation of the sample from MCOV3 and cases of compatible antimeres in BT07 suggest that HRUCI is often bilateral in expression. At present, sample sizes are too small to assess 
trait independence. Inter-trait associations also will be addressed in future research.

Further research on this trait is necessary to verify its genetic nature. Other collections need to be assessed to confirm the differences of frequencies between inland and coastal areas in the Late Prehistory of the Iberian Peninsula. Comparative studies with other archaeological samples are needed to verify if this trait is of local expression or is present in other regions. These studies will be important tools in the assessment of biodistances for populations recovered from prehistoric contexts in the Iberian Peninsula.

\section{ACKNOWLEDGMENTS}

This study was made possible thanks to $\mathrm{PhD}$ Grant SFRH-BD-70495-2010 from Fundação para Ciência e a Tecnologia (Portuguese Ministry for Science, Technology and Higher Education). Our gratitude also goes to the Center of Prehistory at the Instituto Politécnico de Tomar and to the Department of Life Sciences at the University of Coimbra in whose labs the study took place. Academic and institutional support for the research developed also has been granted by the Research Center for Anthropology and Health (CIAS) at the University of Coimbra. This work would not be possible without the consent of Consejería de Cultura y Turismo de la Comunidad Autónoma de Extremadura. We acknowledge the contribution of Dr. Isabel Luna from the Municipal Museum of Torres Vedras and Dr. Luis Barros from the Municipal Museum of Almada for authorizing the study of the osteological collections of Paimogo I and São Paulo II, also discussed in this paper. We acknowledge the support given to our lab work by Perdigões Scientific and Heritage Management Project and ERA-Arqueologia, S.A in allowing the study of the collections of Peridigões and Monte das Covas.

\section{LITERATURE CITED}

Ando S, Kiyokawa K, Nakashima T, Shinbo, K, Sanka Y, Oshima S, Aizawa K. 1967. Studies on the consecutive survey of succedaneous and permanent dentition in the Japa nese chil dren. Part 4: Behaviour of short- r o o t e d teeth in the upper bilateral central incisors. Journal of Nikon University School of Den tistry 9:67-80.
Apajalahti S. 2004. Short Root Anomaly (SRA). Prevalence and phenotypic features in families with emphasis on matrix metalloproteinases in gengival crevicular fluid of SRA and orthodontic patients. PhD dissertation, University of Helsinki, Finland.

Apajalahti S, Arte S, Pirinen s. 1999. Short root anomaly in families and its association with other dental anomalies. Eur J Oral Sci, 107:97101.

Brezniak N, Wasserstein A. 2002a.

Orthodontically induced inflammatory root resorption. Part I: the Basic Science Aspects. Angle Orthodontist, 72:175-179.

Brezniak N, Wasserstein A. 2002b. Orthodontically induced inflammatory root resorption. Part II: the Clinical Aspects. Angle Orthodontist, 72:175-179.

Burnett S, Hawkey D, Turner CG II. 2010. Brief communication: Population variation in human maxillary accessory ridges. Am J Phys

Anthropol 141:319-324.

Edgcomb K, BeGole E, Evans C, Johnson B, Luan X. 2011. Prevalence of short dental roots in four ethnic groups in orthodontic population. Dental Anthropology, vol. 24, 1:11-15.

Fuller J, Denehy G, Schulein T. 2001. Concise dental anatomy and morphology. Fourth Edition. University of Iowa College of Dentistry.

Grorsky M, Bukai A, Shohat, M. 1998. Genetic influence on the prevalence of torus palatino. Am J Medical Genet 75:138-140.

Hölta P, Nyström M, Evälahti M, Alaluusua S. 2004. Root-crown ratios of permanent teeth in a healthy Finnish population assessed from panoramic radiographs. Eur J Orthodontics, 26:491-497.

Hylander WL. 1977. The adaptive significance of Eskimo craniofacial morphology. In Dahlberg AA, Graber TM, editors. Orthofacial Growth and Development. The Hague: Mouton. p 129169.

Irish J. 2006. Who were the ancient Egyptians? Dental affinities among Neolithic through Post dynastic peoples. Am J Phys Anthropol 129:529543.

Jackes M, Lubell D. 1999. Human skeletal biology and the Mesolithic-Neolithic transition in Portugal. L'Europe des derniers chasseurs, $5^{\circ}$ Colloque International UISPP 59-64.

Jackes M, Lubell D, Meiklejohn C. 1997. Healthy 
but mortal: human biology and the first farmers of western Europe. Antiquity 71:639-658.

Jakobsson R, Lind V. 1973. Variation in root length of the permanent maxillary central incisor. Scand J Dent Res, 81:335-338.

Larsen C. 2002. Bioarchaeology: the lives and life styles of past people. J Archaeol Res 10:119-166.

Lind, V. 1972. Short root anomaly. Scand J Dent Res 80:85-93.

Marques L, Generoso R, Armond M, Pazzini C. 2010. Short-root anomaly in an orthodontic patient. Am J Orthodontics and Dentofacial Orthopedics 138:346-348.

Márquez Gallardo JM. 2008. Cerro de Las Baterías, La Albuera (Badajoz) - Memoria de Intervención Arqueológica. Excavation Report. Author's edition.

Matsumura H. 2007. Non-metric dental trait variation among local sites and regional groups of the Neolithic Jomon period, Japan.

Anthropological Science 115:25-33. The

Anthropological Society of Japan.

Mays S. 1998. Archaeology of human bones. London: Routledge.

Miguel L, Brazuna, S. 2008. Relatório dos Trabalhos Arqueológicos - Minimização de Impactes sobre o Património Cultural Decorrentes da Execução da Empreitada de Beneficiação da Rede Viária e Rede de Drenagem do Aproveitamento Hidroagrícola de Alvito -Pisão. Monte das Covas 3. Era Arqueologia SA.

Scott GR. 2008. Dental morphology. In: Katzenberg A, Saunders S, editors. Biological Anthropology of the Human Skeleton. New York: Wiley-Liss, p. 265-298.

Scott GR, Turner, CG II. 1988. Dental Anthropology. Ann Rev Anthropol 17:99-126.

Scott GR, Turner, CG II. 1997. The anthropology of modern human teeth - dental morphology and its variation in recent human populations. Cambridge: Cambridge University Press.

Silva, AM. 1996. O hipogeu de Monte Canelas I

(IV-III milénios a. C.): Estudo paleobiológico da população humana exumada. Trabalho de síntese. Provas de Aptidão Pedagógica e Capacidade Científica. Coimbra, Departamento de Antropologia, Faculdade de Ciências e Tecnologia da Universidade de Coimbra.

Silva, AM. 2002. Antropologia funerária e paleobiologia das populações portuguesas (litorais) do Neolítico Final/Calcolítico. PhD dissertation, Universidade de Coimbra.

Silva, AM. 2003. Portuguese Populations of Late Neolithic and Chalcolithic Periods Exhumed from Collective Burials: an Overview. Anthropologie, XLI/1-2: 55-64.

Silva Filho O, Mateus S, Da Silva V, Oliveira G. 2007. Nanismo radicular - short root anomaly. Revista OrtodontiaSPO Vol. 40, 4:305-310.

Smith B. 1984. Patterns of molar wear in huntergatherers and agriculturalists. Am J Phys Anthropol 63:39-56.

Smith B. 1991. Standards of human tooth formation and dental age assessment. In: Kelley M, Larsen CS, editors. Advances in Dental Anthropology. New York: Wiley-Liss. p. 143-168.

Thongudomporn U, Freer T. 1998. Prevalence of dental anomalies in orthodontic patients. Aus Dent J 43(6):395-398.

Tomé, T. 2011. Até que a Morte nos Reúna: Paleobiologia e Antropologia Funerária da Transição para o Agro-Pastoralismo na Bacia do Tejo e Sudoeste Peninsular. PhD Dissertation. Universidade de Trás-os-Montes e Alto Douro.

Turner CG II, Nichol C, Scott GR. 1991. Scoring procedures for key morphological traits of the permanent dentition: The Arizona State University Dental Anthropology System. In: Kelley M, Larsen CS, editors. Advances in Dental Anthropology. New York: Wiley-Liss. p. 13-31.

Valera A, Godinho R. 2009. A Gestão da Morte nos Perdigões (Reguengos de Monsaraz): Novos dados, novos problemas. Est Arq de Oeiras Vol 17:371-387.

Vargiu R, Cucina A, Coppa A. 2009. Italian populations during the Copper Age: Assessment of biological affinities through morphological dental traits. Hum Biol 81:479493.

Weets J. 2009. A promising mandibular trait in ancient populations of Ireland. Dental Anthropology 22:65-72.

Wu L, Turner CG II. 1993. Brief communication: Variation in the frequency and form of the lower permanent molar middle trigonid crest. Am J Phys Anthropol 91:245-248. 